\title{
MODEL OF SHARIA PRINCIPLES INTEGRATION IN THE APPLICATION OF CAPITAL MARKET LAW
}

\author{
Desy Nurkristia Tejawati \\ Faculty of Law, Wijaya Kusuma Surabaya University \\ e-mail: echyn87@gmail.com \\ Fries Melia Salviana \\ Faculty of Law, Wijaya Kusuma Surabaya University \\ e-mail: friesmelia@gmail.com
}

\begin{abstract}
Indonesia is a country which most of the population is islamic, so of course in the life of the economy should be based on existing principles of sharia. At present, it must be admitted that the principles of sharia have grown in various fields of economy, including Banking, Insurance, and Capital Markets. However, in the Capital Market, although some of its instruments have been found in the Capital Market, the redulation is very minimal. This research is aimed at assisting Financial Services Authority in implementing Roadmap of Sharia Capital Market starting 2015 to 2019 to find a concept of Capital Market Law in accordance with Sharia Principles, so that Sharia Principles can be applied in isolation and different from Market Law regulation Conventional Capital that has been done. Research is a normative juridical research because it focuses on the rules of legislation using empirical data. The approach used is the approach of legislation and concept approach. Sharia Capital Market is a place for investors and emitents whose business field is not contrary to Sharia principles to conduct buying and selling activities in a way that uses the principles of sharia. The implementation of Sharia principles in Shariah Capital Market is in the business field of issuers, contracts used, and there are also arrangements related to Sharia Capital Market Experts.
\end{abstract}

Keywords: Sharia Capital Market Roadmap, Sharia Principles, Capital Market Concept Law.

\section{BACKGROUND}

Capital Market is an reality which coming to moslem area, almost all of country in the world use Capital Market for important economic instrument. The capital market has attracted the attention of various groups, whether investors or enterpreneurs involved in it, but of course with all the material and spiritual consequences that are unwittingly. ${ }^{1}$

Indonesia, as a country with the largest Moslim community in the world, has known Capital Market through its first Stock Exchange which was established in 1912 in Batavia under the name Vereniging voor de Effectenhandel to reactivation with the establishment of the Capital Market Development Board, here in after referred to as Bapepam which will be continuously experienced an increase due to renewal, especially in supporting

\footnotetext{
${ }^{1}$ Burhanuddin S., Pasar Modal Syariah (Tinjauan Hukum), UII Press, Yogyakarta, 2009, p. 2.
}

the legal certainty, especially in 1995 with the Capital Market Law which provides greater opportunities for companies to do go public. ${ }^{2}$

Capital Market, viewed from the side of sharia is part of muamalah activity. Transactions in the Capital Market are permitted to the extent that no transactions are in conflict with the syariah outline, but preferably when activities in the Capital Markets are conventionally separated by the Sharia Capital Market.

The Shariah Capital Market has grown in many countries, not only in Islamic countries such as in the Middle East, Indonesia, Malaysia, and non-Muslim majority countries such as Britain and Germany. The development of sharia capital market can be seen from the development of sharia products such as

2 Bapepam-LK, Profil Pasar Modal, http://www. bapepam.go.id. accessed on 1 August 2017. 
sukuk, sharia shares, and mutual funds sharia. From 1996 to 2013 the third quarter, total sukuk that has been issued in the world as much as 3543 with a total value of $\$ 488.2$ billion $^{3}$. In the Year 2014 to the third quarter of sukuk issued as much as 739 sukuk with a total value of $\$ 99.26$. The five largest sukuk issuing countries are Malaysia, United Arab Emirates, Saudi Arabia, Indonesia, and Qatar. For Islamic mutual fund products, from 2007 to the third quarter of 2013 the number of sharia mutual funds in the world of 786 is worth $\$ 46$ billion. $^{4}$

Indonesia is a country with a large proportion of its population who are Moslem, of course, must also adjust to the existence of Sharia Capital Market. On July 3, 2000, PT. Danareksa Investment Management was issued Sharia Reksadana. Furthermore, the Indonesia Stock Exchange (d/h Jakarta Stock Exchange) in cooperation with PT. Danareksa Investment Management launched the Jakarta Islamic Index (JII) on July 3, 2000, which aims to guide investors who want to invest their funds in Sharia. With the presence of the index, then the investors in the Indonesia Stock Exchange has provided stocks that can be used as a means of investing in accordance with the principles of Sharia. ${ }^{5}$

On April 18, 2001, for the first time the National Sharia Council of the Indonesian Council of Ulama (DSN-MUI) issued a fatwa directly related to the capital market, namely the fatwa No. 20/DSNMUI/IV/2001 on Guidelines for Implementation of Investment for Sharia Mutual Funds. Furthermore, Shariah investment instruments in Indonesian Capital Market continue to increase with the presence of Syariah Bonds PT. Indosat Tbk in early September 2002. This instrument is the first Syariah Bond and the contract used is a mudharabah contract.

Fatwa the National Sharia Council of the Indonesian Council of Ulama No. 32/DSN-MUI/ IX/2002: Sharia bonds are long-term securities based

\footnotetext{
3 Zawya, Sukuk Perceptions and Forecast Study 2014, http://www.iefpedia.com/english/wp-content/uploads/2014/01/ tr-sukuk-perceptions-and-forecast-20143.pdf acessed on 1 August 2017.

4 Zawya, Sukuk Perceptions and Forecast Study 2015, http://www.iefpedia.com/english/wp-content/uploads/2014/01/ tr-sukuk-perceptions-and-forecast-20143.pdf acessed on 1 August 2017.

${ }^{5}$ Andri Soemitra, Bank dan Lembaga Keuangan Syariah, Kencana, Jakarta, 2010, p. 117.
}

on Sharia principles issued to the Issuer holders of Sharia Bonds obliging the Issuer to pay income to the holders of Syariah Bonds in the form of profit/ margin/fee, and pay back the funds bonds at maturity. ${ }^{6}$

PT. Indosat Tbk has issued the first Syariah bonds in Indonesian Capital Market with yield rate of 16, $75 \%$, a high rate of return compared to the average return of bonds with the usury or conventional principle.In 2003, the majority of shares listed on the Jakarta Stock Exchange (BEJ) consisted of 333 listed listed companies, including 236 shares in accordance with Sharia principles and eligible for transactions in the Sharia Capital Market.

Sharia Capital Market in the last five years has increased considerably. ${ }^{7}$ Nevertheless, the existing legal arrangements or Capital Market instruments are still not based on Sharia Principles, making the Sharia Capital Market Roadmap beginning in 2015 and ending in 2019.

\section{PROBLEM RESEARCH}

Based on the description of the background that has been described above in this study formulated the following problems: What are the legal characteristics of the Capital Market based on sharia principles under the Sharia Capital Market Roadmap?, How is the application of Capital Market Law based on sharia principles based on the Sharia Capital Market Roadmap?

\section{METHOD}

Research is a normative juridical research because it focuses on the rules of legislation using empirical data. The approach used is the approach of legislation and concept approach.

\section{DISCUSSION}

Capital Market is a long-term securities trading, either in the form of own capital (stock) or debt (bonds), either issued by the government, or by private companies. ${ }^{8}$ Article 1.13 of Law No. 8 of 1995 Concerning Capital Markets states that the

\footnotetext{
${ }^{6}$ Bapepam-LK, Kajian Pasar Seknnder Efek Syariah di Pasar Modal Indonesia. http://bapepam.go.id/syariah/ publikasi/riset/index.html accessed on 2 May 2016.

${ }^{7}$ Andri Soemitra, Op Cit, p. 12.

8 Budi Untung, Hukum Bisnis Pasar Modal, Andi, Yogyakarta, 2011, p. 7.
} 
Capital Market is an activity concerned with the public offering and trading of securities, public corporations, relating to its issuing securities and securities-related institutions and professions.

Sharia Capital Market is not contained in Capital Market Law, but Sharia Capital Market can be interpreted as activity in Capital Market as regulated in Capital Market Law which is not contradictory with sharia principles, as mentioned in Regulation of Financial Service Authority Number 15/POJK.04/2015 concerning Implementation of Sharia Principles in Capital Market, hereinafter referred to as OJK Regulation concerning Sharia Principle, in Article 1 number 4, those are activities related to Sharia Public Offering, Sharia Securities Trading, Sharia Investment Management in Capital Market, and Issuer or Public Company relating to its Sharia Securities, Securities Companies that are partly or entirely based on sharia principles, as well as institutions and professions related to Sharia Securities.

The National Sharia Council (DSN) of the Indonesian Ulama Council (MUI) 40/DSNMUI/X/2003 about Capital Market and How to do Sharia Principal in Capital Market, issued a fatwa on the permissibility of transactions in the Capital Market as long as the object is not contrary to Sharia Principles. As for what is considered to be contradictory are: First, the conduct of the transaction shall be conducted according to the principle of prudence and shall not speculate and manipulate in which it contains elements of dharar, gharar, riba, maisir, risywah, immoral and tyranny. Second, the act of transaction speculation containing elements of dharar, gharar, riba, maisir, risywah, immoral and tyranny as meant in paragraph 1 above includes: Najsy, that is, to make a false offer; Bai 'al-a'dum, ie selling of goods (sharia securities) that have not been owned (short selling); and Insider trading, ie using inside information to gain profit on forbidden transactions; Cause misleading information; also investing in issuers (companies) that at the time of transaction level (ratio) of corporate debt to financial institutions ribawi more dominant than capital; Margin trading, which is to conduct transactions on syariah securities with interest-based loan facilities on the obligation to settle the purchase of such sharia securities; Ikhtikar (hoarding), ie making purchases or and collection of a Sharia effect to cause changes in the price of Islamic securities, with the aim of influencing other parties; And other transactions containing the above elements.

Sharia Principles based on the Sharia OJK Regulation on Article 1 point 2 are Islamic legal principles in Sharia Activities in Capital Market based on the National Sharia Council - Majelis Ulama Indonesia, as long as the fatwa does not conflict with this Regulation of Financial Services Authority and/ or the Regulation of the Financial Services Authority based on the fatwa of the National Sharia Board Majelis Ulama Indonesia.

The Sharia Supervisory Board, pursuant to Article 1 Sub-Article 5 of the OJK Regulation concerning Sharia Principles, is the board responsible for providing advice and advice and oversee the fulfillment of Sharia Principles in the Capital Market for Persons conducting Sharia Activities in Capital Market, whereas the Sharia Capital Market Expert, hereinafter referred to with ASPM, pursuant to Article 1 Sub-Article 6 of OJK Regulations concerning Sharia Principles are: an individual possessing knowledge and experience in the field of sharia; or; business entities whose boards and employees possess knowledge and experience in the field of sharia giving advice and or oversee implementation of Sharia Principles in the Capital Market in the business of the enterprise and/or giving Shari'ah compliant statement on Sharia products or services in the Capital Market.

Activities and types of business that are contrary to Sharia Principles in the Capital Market, in Article 2 of the OJK Regulation concerning Sharia; gambling and gambling games; rural financial services; buying and selling risks that contain elements of uncertainty (gharar) and/or gambling (maisir); and; manufacture, distribute, trade, and or otherwise provide: Haram substance (haram li-dzatihi); Unlawful goods or services not because of the substance (haram lighairihi) stipulated by the National Sharia Council - Majelis Ulama Indonesia; and/or goods or services that undermine morals and are harmful.

Transactions that are contrary to Sharia Principles in the Capital Market include: trading or transactions with bids and/or false requests; trades or transactions not accompanied by the delivery of goods and/or services; trade on goods not yet owned; 
purchase or sale of Securities using or utilizing inside information from Issuers or Public Companies; Margin transaction on Sharia Securities with interest element (usury); Trade or transaction with purpose of holding (ihtikar); Conducting trades or transactions containing elements of bribery (risywah); and Other transactions containing speculative elements (gharar), fraud (tadis), include concealed ghysysy, and attempts to influence other lies (taghrir).

\section{Sharia Capital Market Characteristic Sharia Capital Market Investor}

While associated with investors who use the Sharia Capital Market may do not know about the characteristic of the Sharia Capital market.

The first program is the creaton of Sharia Capital Markets branding thorugh logo, tagline, and video of Sharia Capital Market. Second program through socialization and education of Sharia Capital Market to Community such as procurement of Sharia Capital Market School, Sharia Capital Market roadshow or social media, Financial Services Authority.

Third program is to work with relevant institutions to include Sharia Capital Markets material in the Higher Education curriculum by preparing Sharia Capital Market material studies for the Higher Education curriculum, in coordination with relevant ministries and institutions to include Sharia Capital Market material in the Higher Education curriculum, as well as providing training on Sharia Capital Market to the lecturers of economics in Higher Education, while the activities undertaken are cooperation with several universities by establishing Mini Stock Exchange.

Fourth program is to work together in order to promote Sharia Capital Market to the international world by cooperating with international institutions and participating in international sharia capital market event has not been conducted.

\section{Human Resources}

Intermediary Securities, in Sharia Capital Market plays a role that is not less important when compared with Investors, therefore knowledge of Brokerage Securities associated with the characteristics required. The securities intermediary is more familiar with the characteristics of the Shariah Capital Market, but the Securities Brokerage only recognizes the economic characteristic of the Shariah Capital Market, not the legal characteristic, so that the Brokerage also requires socialization.

The Sharia Capital Market Roadmap places intermediaries of securities and human resources in the $3^{\text {rd }}$ direction, namely Human Resources Development and Information Technology of Shariah Capital Market into two programs are: increasing the quantity and quality of Human Resources. This program is conducted by entering Sharia Capital Market material in professional standard test and continuing education for supporting professions conducting activities in Capital Market, and cooperating with related parties to facilitate education and training of Sharia Capital Market for Market Participant and to manage Sharia Capital Market. So that the profession in the field of Sharia Capital Market.

Regulation of the Financial Services Authority Number 16/POJK.04/2015 Concerning Capital Market Sharia Experts, hereinafter referred to as OJK Regulation of ASPM, is a follow up of direction III of the Sharia Capital Market Roadmap. Article 1 The OJK Regulation of ASPM states that the Sharia Capital Market Expert may be conducted by an individual or business entity providing advice and or supervising the implementation of Shariah compliance statement on Sharia products or services in the Capital Market, so that according to Article 3 the Sharia Expert Team is the team responsible for Sharia conformity of Sharia products or services in the Capital Market issued or issued by the company.

Sharia Capital Market Experts obtain permission from the Sharia (Islamic) Authority which is valid for 5 years and may be extended. Sharia Capital Market Expert can become a member of Sharia Supervisory Supreme in at most 4 companies conducting activities in the Capital Market.

This program is implemented by establishing and managing the Sharia Capital Market dashboard, establishing Sharia Securities List Information System (SIDES), and establishing Sharia Capital Market based technology information system.

\section{Sharia Capital Market Product}

Sharia Capital Market Products in the Sharia Capital Market Roadmap are included in Direction II of Supply and Demand Confirmation of Shariah 
Capital Market products. Sharia Capital Markets products consist of sharia and shariah mutual funds that are still relatively small compared to sharia capital market products, therefore it is necessary to make efforts to encourage the growth of Sharia Capital Market products. ${ }^{9}$

\section{First, Sharia Shares}

Stock is one of the securities that has ownership properties for its holders. Shareholders have the advantage of getting dividends. However, there are some shareholders who want to profit from capital gains, so have no desire to hold shares for too long.

Sharia shares began its publication on July 3, 2000 at the time of PT. Danareksa Investment Management, which cooperates with Indonesia Stock Exchange (IDX), launches Jakarta Islamic Index (JII) Issuer whose business field is not in contradiction with Sharia Principles, will fullfill the criteria as Sharia based on List of Sharia Securities (DES). referred to as DES, first published in 2007 as the implementation of Regulation No. II.K.1 on Criteria and Issuance of List of Sharia Securities Furthermore DES is updated periodically 2 (two) times a year, ie at the end of May and end of November In addition, DES is also issued incidental on shares of issuers that have been effective on their registration statement and fulfill the criteria as sharia shares.

Sharia stock trading's process, can be seen from the movement of sharia stock index available in Indonesia Stock Exchange (ISSI) and Jakarta Islamic Index (JII). ISSI presented all sharia shares listed on the exchange while JII presented 30 sharia shares with the largest market capitalization and the most liquid ones traded.

Investors apparently have an interest in sharia shares. This can be seen from the increasing number of Sharia shares in the List of Sharia Securities (DES).

Sharia shares are traded stocks coming from issuers that meet Sharia criteria that are not interestbased, harmful, halal of the issuer's business activities, no unethical and immoral transactions such as market manipulation or insider trading, and using sharia principles.

\footnotetext{
${ }^{9}$ Otoritas Jasa Keuangan, Roadmap Pasar Modal Syariah 2015-2019, http://www.ojk.go.id/Files/box/roadmappms_2015-2019 accesed on 12 June 2017.
}

Article 1 point 1 Regulation of the Financial Services Authority Number 17/POJK.04/2015 on Issuance of Sharia Securities Issuance and Requirements Shares by Sharia Issuer or Sharia Public Company, hereinafter referred to as POJK of Sharia Issuer, stipulates that Sharia Issuer is an issuer whose articles of association and the type of business and the way of managing its business based on Sharia Principles in Capital Market as stated in the Articles of Association and having Sharia Supervisory Board.

Article 2 point 1 POJK The Sharia Issuer declares that Sharia Issuer or Sharia Public Company issuing Sharia Securities in the form of shares shall comply with the provisions in the Regulation of the Financial Services Authority.

Article 1 point 3 POJK The Sharia Issuer stipulates that in the event that the activities and business type of Issuer or Sharia Public Company no longer fulfill Sharia Principles, the Issuer's activity is no longer a Sharia Issuer, any Sharia Issuer activity using Mudharabah and Ijarah Agreements for Initial Market while for Market Secondary prohibits the existence of Margin Purchase and the existence of Short Sale Sale.

The Shariah Issuer is evaluated once every 6 months and listed in the Sharia Sharia Index. This List of Sharia Securities is issued by the Financial Services Authority and has an important role for Shariah equity investors as well as sharia mutual funds, or sharia insurance in choosing its portfolio. List of shares included in the calculation of Indonesia Sharia Shares Index (ISSI) for the period of June 2017 - November 2017 at Indonesia Stock Exchange (IDX) in accordance with the announcement of Indonesia Stock Exchange No. Kep-19/D/04/2017, dated May 17, 2017 which is effective since June 2, 2017 as many as 335 shares (listed list of issuers in the list of attachments).

\section{Second, Sukuk}

Sukuk shall be regulated in the Regulation of the Financial Services Authority Number 18/ POJK.04/2015 concerning Issuance and Sukuk Requirements, hereinafter referred to as POJK Sukuk. Article 1 POJK Sukuk states that Sukuk is a Syriah Securities in the form of a certificate or proof of ownership of equal value and represents a part of equal value and represents an inseparable 
or undivided share (syuyu/undivided share) on the underlying asset with the underlying asset in contradiction to the Sharia Principle, has a value for the benefit of tangible assets, existing or existing services, specific projects or investment activities as determined in Article 2.

Article 4 POJK Sukuk states that Issuer is obliged to comply with the provisions in the Regulation of the Financial Services Authority, including the existence of syariah compliance statement on Sukuk in Public Offering of Issuer Sharia Board or Sharia Expert Team, so that based on Article 10 POJK Sukuk if there is a change of type of syariah Sukuk, and the absence of assets, the Sukuk no longer becomes Edek Syariah and Sukuk is turned into accounts receivable.

Issuance of Sukuk, based on Markets 7 POJK Sukuk shall include, the results of the sukuk rating, sukuk agreement, akadyariah used in the issuance of sukuk, the issuer's statement concerning the asset, the statement of the sukuk trustee, the statement of the issuer to make the payment of proceeds, majin, or fee, as long as the asset under which the Sukuk is still available, and the underwriting agreement.

By the end of 2014, there are 71 Sukuk issued and only 35 Sukuk in circulation, so for the increasing number of issuers issuing Sukuk, there is a need to encourage issuers and companies or institutions that have the potential to issue Sukuk.

\section{Third, Mutual Funds Sharia}

The market share of Sharia Mutual Funds is still very far when compared ${ }^{10}$ with the conventional Mutual Fund market share. Regulation of the Financial Services Authority Number 19/POJK.04/2015 On the Issuance and Requirements of Sharia Mutual Funds, hereinafter referred to as POJK Reksadana Syariah, in Article 1 point 1 states that Sharia Mutual Funds are Mutual Funds as referred to in the Capital Market Law and its management does not conflict with the Sharia Principles in the Capital Market. ${ }^{11}$

Article 6 POJK Reksadana Syariah states that Sharia Principles in Capital Market if the contract, its management and portfolio are not contradictory to Sharia Principles in Capital Market.

Issuance of Sharia Mutual Funds has two forms, issuance of shares of Mutual Funds in the form of

\footnotetext{
${ }^{10}$ Ibid.

11 Ibid.
}

a Company and Participation Unit Units of Sharia Mutual Fund in the Form of Collective Investment Contract.

Article 3 states that Sharia Reksadana may be:

First, Sharia Money Market Mutual Funds; Money Market Sharia Mutual Funds, pursuant to Article 19 of POJK Mutual Fund Syariah, declare that the investment manager managing Sharia Money Market Mutual Fund shall be obliged to invest in domestic syariah money market instruments, either in rupiah denomination or other currency denomination and or permanent Sharia Securities issued with a period of not more than 1 year and or the remaining maturity of not more than 1 year.

Second, Sharia Reksadana Fixed Income; Article 1 point 2 POJK Reksadana Syariah declares that Sharia Securities that provide fixed income with maturity of 1 year or more, including permanent Sharia Securities that can be converted. Article 20 POJK Mutual Fund Syariah states that the investment manager managing Shariah Mutual Funds of Fixed Income shall invest at least $80 \%$ of the Value of Assets in the form of fixed-income Sharia Securities.

Third, Sharia Mutual Funds Shares; Sharia Mutual Funds Shares are shares of Shares based on Article 2 POJK Sharia Issuers are Shares issued from Sharia Issuers whose articles of association state the activities and types of business and business management based on Sharia Principles in the Capital Market. Article 21 POJK Mutual Fund Syariah states that the investment manager that manages Sharia Reksadana Shares must invest at least $80 \%$ of Net Asset Value in the form of Sharia Securities that are equity.

Fourth, Mixed Sharia Mutual Funds; Article 22 POJK Reksadana Syariah states that the investment manager managing Mixed Sharia Mutual Funds may only invest in Fixed Shariah Securities, Sharia Securities are equity and/or domestic money market instruments in accordance with Sharia Principles in Capital Market with the provision of investment in one such investment instruments shall be at most $79 \%$ of the Net Asset Value and the portfolio of such Sharia Mutual Funds shall contain Sharia Securities in the form of equity and Fixed Income Sharia Securities.

Fifth, Protected Sharia Mutual Funds; Article 23 POJK Reksadana Syariah states that the party 
conducting the Sharia Secured Sharia Securities Public Offering is obliged to comply with laws and regulations in the Capital Market sector governing Guidelines for the Management of Protected Mutual Funds, Guaranteed Funds, and Index Mutual Funds as well as regulations in the Capital Market Sector to regulate other Mutual Funds related to the offering period or the number of shares or units of investment that are limited and not continuous and with the information that the percentage of the Net Asset Value of Protected Sharia Mutual Funds to be invested in the Tetrap Income Sharia Securities, syariah money market instruments and Sharia Securities other and types of Sharia Securities portfolio which become the basis of protection is by investing in the Sharia Securities of Fixed Income which fall into the category of investment worth so that the value of Sharia Securities Fixed Income at maturity can at least $\mathrm{m}$ cover the amount of the protected value and the criteria of Syaruah Securities and/or syariah money market instruments as set forth in Article 25 POJK of Islamic Mutual Funds.

Sixth, Sharia Index Mutual Funds. Article 27 POJK Reksadana Syariah states that the party conducting the Sharia Index Mutual Bid Offering must comply with laws and regulations in the Capital Market sector governing Guidelines for the Management of Protected Mutual Funds, Guaranteed Funds, and Index Mutual Funds as well as regulations in the Capital Market Sector regulates the other related Mutual Funds with the offering period or the number of shares or units of participation that are continuous or limited in either the offering period or the number of shares or Participation Units offered. The Investment Manager, pursuant to Article 29 POJK of the Sharia Mutual Fund, states that it is obliged to provide additional information in the Prospector regarding the terms of the investment of at least $80 \%$ of the Net Asset Value of Sharia Mutual Funds shall be invested in Sharia Securities that are part of a set of Sharia Securities with the weighting of each Securities Shari'a in Shariah Mutual Funds The index is at least $80 \%$ and at most $120 \%$ of the weighted of each of the Sharia Securities in the index referred to by the level of deviation from the performance of the Syariah Index Mutual Fund, and shall use the index based on Sharia Securities.
Sevent, Sharia Based Islamic Sharia Based Mutual Funds; Article 1 point 7 POJK Reksadana Syariah states that Sharia Foreign Securities are Sharia Securities offered through a Public Offering and / or traded on the Stock Exchange abroad and contained in the List of Sharia Securities.

Eighth, Syariah-Based Mutual Funds; Article 1 point 3 POJK Syariah-based Sukuk Mutual Fund is a Mutual Fund investing in one or more Sukuk with a composition of at least $85 \%$ of Net Asset Value of Sharia Mutual Fund invested in Sukuk offered in Indonesia through Public Offering, State Sharia Securities and/or Letter Valuable Sharia Commercials with maturities of 1 year or more and qualified as investment categories and included in the Collective Custody at the Depository and Settlement Institution by the commercial issuers of sharia commercial securities.

Ninth, Sharia Mutual Fund in the form of Collective Investment Contract with Participation Unit traded on the Exchange; The Mutual Fund Collective Investment Contract, pursuant to Article 15 point 3 of the OJJ Sharia Obligation shall include the Investment Manager and Custodian Bank as a representative acting for the benefit of Participation Unit holders as represented parties where the Investment Manager is authorized to manage the collective investment portfolio of the Custodian Bank authorized to execute Collective Custody with akad, way of managing, and portfolio of Sharia Mutual Fund in the form of Collective Investment Contract is not contradictory to Sharia Principle in Capital Market.

Tenth, Sharia Mutual Funds In the form of Collective Investment Contract of Limited Participation. Article 14 POJK Reksadana Syariah declares that the party conducting Public Sharia Securities Participation Unit In the Form of Collective Investment Contract shall be subject to the laws and regulations in the Capital Market sector regulating the general requirements of Submission of Registration Statements, the laws and regulations in the Capital Market sector governing the Registration Statement In the framework of Public Offering of laws and regulations in the Capital Market sector governing Mutual Funds in the form of Collective Investment Contracts, and laws and regulations in 
the Capital Market sector governing Mutual Funds in the form of other Collective Investment Contracts.

\section{Fourth, Sharia Asset Backed Securities}

Article 3 Regulation of the Financial Services Authority Number 20/POJK.04/2015 on Issuance and Conditions of Sharia Asset Backed Securities, hereinafter referred to as POJK EBA Syariah, Sharia Asset Backed Securities in the form of Letters of Participation hereinafter abbreviated as EBAS-SP are Sharia Asset Backed Securities issued by The publisher whose contract and portfolio are in the form of Collection of Receivables or Housing Financing which are not contradictory to the Sharia Principles in the Capital Market as well as proportionately proportional ownership owned by the EBAS-SP holder.

Article 2 POJK EBA Syariah states that the Sharia Asset Backed Securities Collective Investment Contract is a Contract between the Investment Manager and the Custodian Bank which holds the holder of the Sharia Asset Backed Securities wherein the Investment Manager is authorized to manage the collective investment portfolio and the Custodian Bank is authorized to carry out Collective Custody its implementation does not conflict with the Sharia Principles in the Capital Market.

Sharia Asset Backed Securities issued by Sharia Asset Backed Securities Collective Investment Contract, hereinafter referred to as Sharia Asset Backed Securities, is an Asset Backed Securities whose portfolio consists of other financial assets, contract and method of management are not contrary to Sharia Principles in the Capital Market.

\section{Akad Used in Issuance of Sharia Securities in the Capital Market}

Regulation of the Financial Services Authority Number 53/POJK.04/2015 Concerning Agreements Used in Issuance of Sharia Securities in Capital Market in Article 1 are:

First, Ijarah is an Agreement (akad) between the lessor or the service provider and the parties the landlord or service provider (mu'jir) and the tenant or the service user (musta'jir) to transfer the use rights to an Ijarah object which may be of benefit goods and/or services within a certain time with rent and/ or wage payment (ujrah) without being followed by the transfer of ownership of the Ijarah object it self;

Second, Istishna is an agreement (akad) between the buyer or the buyer (mustashni') and party maker or seller (shani') to create Istishna objects purchased by parties buyer or buyer (mustashi') with the criteria, requirements, and specifications agreed both parties;

Third, Kafalah is the agreement (akad) between the guarantor (kafiil/guarantor) and the party guaranteed (makfuul 'anhu/ashii/person owed) to guarantee the obligations of those parties guaranteed to the other party (makfuullahu/the indebted person).

Fourth, Musharaka is an agreement (akad) cooperation between the owners of capital (shahib al- mall) and the manager of the business (mudharib) by the owner of capital (shahib al-mal) hand over capital and business management (mudharib) manage the capital in an effort;

Fifth, Musharaka is agreement (akad) cooperation between two or more parties (syarik) by including capital both in the form of money and other forms of assets to conduct a business;

Sixth, Wakalah is the Agreement (akad) between the power (muwakki) and the parties the power of attorney (representative) by way of the party receiving the power (muwakki) authorizes to the party receiving the power (representative) to perform certain actions or actions.

\section{The Implementation of Sharia Priciples In Capital Market}

Treasure is something that man desires, with the option of using or storing and using it someday. So the treasure can be regarded as something of value. ${ }^{12}$ Treasures can be divided into five types: a. Real or tangible assets or ain; b. Unreal property or unreal (intangible assets) that sums up all the shaped property intellectuals and so on; c. Benefits and benefits of the use of assets whether real assets or unreal assets; d. Money; e. Rights in the form of finance. ${ }^{13}$

12 Ibnu Abidin, Muhammad Amin Bin Umar, Hasyiah Radd al-Mukhtar ala Durr al-Mukhtar, Dar Mustafa al-Baby al-Halaby, Mesir, 1998, p. 7.

${ }^{13}$ Mohd Daud Bakar, Structuring Islamic PDS; Role of Independent Syari'ah Adviser, Seminar on Islamic Private Debt Securities (IPDS), Suruhanjaya Sekoriti, Malaysia, 24-25 September 2001, p. 5-6. 
Financial rights can be divided into two, namely financial rights in the form of assets (maly'aini rights), where this right has a link to property and has the value of wealth and financial rights are not in the form of assets (hak maliy fi al-dimmah). ${ }^{14}$ In relation to that right, the transfer of benefit, or alteration of rights is allowed as far as it is sold to the seller if the price is not higher than the agreed price. ${ }^{15}$

Investment is an activity that develops assets in certain ways that engage activities and risks here, so that by itself it will accept the possibility of risk from the activity, as well as if investors invest in the Sharia Capital Market. Investors will receive profit or loss, which is certainly close to things that are prohibited by syara', such as usury, gharar, and helah. Therefore it is necessary to pensyariatan a law in Islam so that investors do not make investments that are prohibited by syara'. In the Capital Market, the administration is conducted by the fatwa of the National Sharia Board - Ulama Council of Indonesia, and supervised by the Sharia Supervisory Board, as mentioned in Article 1 of the Financial Services Authority Regulation No. 15/POJK.04/2015, here in after referred to as POJK Syariah Principle.

Sharia Activities, based on POJK Sharia Principles are activities related to Sharia Public Offering, Sharia Securities trading, Sharia investment management in the capital market, and publicly-listed issuers or companies related to Sharia securities, and Securities Companies that are partly or entirely based on sharia principles as well as institutions and professions related to Sharia Securities.

Issuer, in Sharia Capital Market, pursuant to Article 2, shall have business which is not contradictory to Sharia principles, that is gambling, usury, gharar, trading of haram or haram goods as determined by the National Sharia Council - Majelis Ulama Indonesia, and goods damaging morals. This activity is always under the supervision of the National Sharia Council, so that every 6 months the National Sharia Board will issue a list of issuers in accordance with the principles of sharia. For issuers deemed to have been unsuitable, the issuer is not

\footnotetext{
14 Nazaruddin Abdul Wahid, Sukuk, Ar-Ruzz Media, Yogyakarta, 2010, p. 79.

${ }^{15}$ Abdul Aziim Islahi, Economic Concept of Ibnu Taimiyyah, The Islamic Foudation, Leicester, 1988, p. 75-102.
}

allowed to engage in activities within the Sharia Capital Market.

Markets 1 POJK Sharia Principles declare that the Sharia Securities in the Capital Market Law and its implementing regulations on which the contract, the manner of management, business activities, assets on which the contract is based, the manner of management, business activities and or assets related to such securities and the issuer are not contrary to Sharia Principles in Capital Market. This is because the management of capital is not done with things that are contrary to Sharia Principles, so the benefits received will be not kosher.

As the sale and purchase of shares in the Conventional Capital Market, the sale and purchase of shares in the Shariah Capital Market is conducted either in the Primary Market or in the Secondary Market. Sale and Purchase in Primary Market by using a contract permitted by Sharia Principles based on POJK Syariah Securities, namely Istishna, Mudharabah, or Musyarakah, while on the Secondary Market, there are two activities that are prohibited is the purchase of margin, because marjim purchase is a process of buying and selling by do borrowing to securities companies, it can be said to contain elements of interest or usury while short sale, is the sale and purchase of an item that does not exist.

Sharia Mutual Funds for issuers follow the list issued by the Sharia Supervisory Board related to activities that are not sharia to clean from unlawful. Procedures of selling by using a contract in accordance with Sharia Principles based on POJK Syariah Securities.

Sharia Mutual Fund which is the first securities issued by Danareksa has 10 kinds of forms that can be traded either in the form of the Company or in the form of Collective Investment Contract. The statutes are conducted in POJK Reksadana Syariah and traded in both the Primary Market and the Secondary Market.

The Shariah Capital Market, especially in the stock of trading in the Secondary Market, is basically feared by some parties that there may be violations in sharia principles, especially Helah.

Helah can occur in relation to the occurrence of gharar, gharar based on the hadith of the Prophet like, "From Ali, Rasulullah SAW never forbade buying and selling of forced people, buying and selling 
gharar and buying fruit until cooked" (Muslim HR), so it can be said that the gharar haram. Gharar is something interesting but it is not clear, it is related to the sale price, price type, or trickery. ${ }^{16}$

Violations of Sharia Principles can also occur from the difference in purchases, where the investor sells in the Secondary Market to buy securities at a low price and then sell them for a very high price.

The difference in purchases or the concept of profit in the Islamic economic concept is contained in verse 19 of Surah Al-Baqarah, that profit is the sum of the exchange rate of something it holds with something of an exchange value equal to or exceeding the purchase price.

Fair profit is defined profit under fair and simple circumstances, in accordance with the law of supply and demand and applies in the free market provisions under the provisions of state law, or other influences not interfere in the system of sale and purchase, production, and providing commodity but fully applicable free competition. ${ }^{17}$ Something goods or processes that occur to a product and the existing habits in a place and the stages of problems encountered.

Hadith of the Prophet "And Amir Ibn Saad ibn Abi Waqas from his father he said: the year of the final pilgrimage (haj wada') Rasulullah was visited me when I was tired, then I said actually I am now in a state of illness, but I have a lot of wealth if I charity $2 / 3$ of my wealth, the Apostle replied no, then the Apostle said 1/3 and 1/3 were big and many" (HR Imam Al Bukhari).

Sukuk is a root word rather than Arabic "sakk", plural sukuk or skai or sakaik meaning to hit or hit. This term stems from the act of putting a person's hand on a document representing a contract for the establishment of rights, bonds, and money. In modern concepts are mentioned as securing financing that gives rights to property and liabilities as well as other forms of property rights. ${ }^{18}$

${ }^{16}$ Ahmad Muhammad Al-Assal, Sistem, Prinsip, dan Tujuan Ekonomi Islam, Terj. Drs. H. Imam Saefudin, Pustaka Setia, Bandung, 1999, p. 73.

17 Khurshid Ahmad, Studies in Islamic Economic, United Kingdom and King Abdul Aziz University, The Islamic Foundatioan, Jeddah, 1998, p. 141.

${ }^{18}$ Nathif J. Adam and Abdulkader Thomas, Islamic Bonda, Your Guide to Isuing, Structuring and Investing in Sukuk, Euromoney Books, London, 2004, p. 43.
Sukuk have differences from bonds. If the bond is a debt, then sukuk is the asset's asset. Sukuk is the underline of investment in the form of objects or goods, while the bond is a debt, so the return of money.

Applications commonly used in sukur are Sukuk Ijarah application, Sukuk Salam application, Sukuk Murabahah Application, Sukuk Mudharabah Application, Istisna Sukuk Application, Hybrid Application.

Sukuk in Indonesia, set out in the POJK Sukuk, which in Article 1 states that the Sukuk is a Sharia Securities in the form of certificates or proof of ownership of equal value and represents an integral or undivided portion of the underlying asset.

Assets are tangible assets and financial assets are the right to profit the originator, the originator may act freely in exploring assets for profit, can sell, rent or pledge. ${ }^{19}$

Investors do not want asset goods but intend to invest in business activities that are deemed to be profitable, and usually issuers are entitled to recover their assets using a contract known as bay'al-wafa', but it is usually rarely made this form of contract. Originator only sells assets to SPV securing assets by using the allowed contract by using Sukuk. SPV managing assets, the results will be distributed to Investors. ${ }^{20}$

Article 2 POJK Sukuk states that the assets on which the Sukuk is based shall not be inconsistent with the Sharia Principles in Capital Market and comprise: a. certain tangible assets; $b$. the value of the benefits of certain tangible assets either existing or existing; c. existing or existing services; d. certain project assets and or; e. Investment activities that have been determined.

SPV is not available in Sukuk settings in Indonesia. Sukuk issuance is performed by the owner which in this case is called the issuer. With the requirements set forth in Article 3 of the POJK Sukuk, the requirements as referred to in the Sukuk rating, the agreement of the Sukus Trustee, the contracts used, the declaration are not contradictory to Sharia Principles, Good Faith, Shari'a Conformity

\footnotetext{
${ }^{19}$ Muhammad Yusuf Musa, Al-Amwal wa nazariyyat al'aqad fi al-Fiqh al-Iskamiy, Dar al-kutub al-Arabiy, Mesir, 1952, p. 161 .

${ }^{20}$ Nazaruddin, Op.Cit., p. 111.
} 
as well as the securities underwriting agreement as stated in Article 7 which avoids the occurrence of gharar, either to knowledge, products, or prices.

Gharar is also avoided because Article 10 POJK Sukuk states that Sukuk is no longer a Sharia effect if the condition no longer has assets that are the basis of Sukuk and or there is a change of type of syariah contract, the contents of syariah contract and/or assets which become the basis of Sukuk, Principle of Sharia in Capital Market, and when it happens, the Sukuk is changed into accounts receivable and the issuer must settle the obligation on the debts to the Sukuk holders.

The Qur'an and Sunnah have prohibited usury in trading contracts, exchange of commodities, and in various forms of transaction (dayn). The prohibition of usury is contained in the Qur'an Al-Surah Al Baqarah 275, 278, Surah Al Nisa 161, and Ali Imran 130.

While the Sunnah has also forbidden, as Rasul SAW said: Be ready to buy gold with gold, silver with silver, barli with barli, applied with applying, salt with salt degan the same amount of handover done in assemblies.

Hence the form of Sukuk is not a form of bond which is the ownership of bonds such as bonds on the basis of debt agreements such as bonds. This is because if the basic agreement is a debt agreement can lead to usury. While Sukuk is an underline asset that can be done with ownership so that the basic contract that is used can be various, except mudharabah, akad permitted in Sharia Principles.

Asset Backed Securities even though it has been regulated in POJK EBA Syariah, but in practice there is still no implementation, but basically the same as conventional EBA which is a debt agreement but using the profit sharing system.

Article 2 paragraph 2 prohibits this activity in sharia transactions: a. trades or transactions with false offers or requests; $b$. trades or transactions not accompanied by the delivery of goods or services; c. trade on goods not yet owned; d. purchases or peyang use or utilize inside information from issuer or public company; e. margin transaction on the effect of sharia containing elements of usury; f. trade or transactions for the purpose of hoarding; g. conduct trading or transactions containing bribery elements; h. Transasksi contains elements of speculation, fraud, including hiding defects and attempts to influence others containing lies.

\section{CONCLUSION AND RECOMMENDATION Conclusion}

First, The Sharia Capital Market Roadmap focuses on several issues, the first being the socialization of the Sharia Capital Market in order to become better known, the Issuer who can sell the securities issued in Sharia Capital Market, the establishment of the Sharia Capital Market Expert, what securities can be traded in the Sharia Capital Market, and of course any contract that is used in Sharia Capital Market.

Second, The fimplementation of Sharia Principles in Sharia Capital Market lies in the business field of issuers that should not conflict with Sharia Principles, Sharia effects, contracts used must be contracts that are not contrary to the Sharia Principles.

\section{Recommendation}

First, Implementation of Sharia Capital Market Roadmap that must be implemented with an increase every year, it is of course accompanied by supervision by the financial services authorities in order to avoid devitions from Sharia Principles;

Second, Laws and regulations relating to sharia capital market must be made immediately for the existence of legal certainty in the protection of investors so as to increase the interest in the capital market.

\section{REFERENCE \\ Regulations:}

Undang-Undang Nomor 8 Tahun 1995 tentang Pasar Modal, Lembaran Negara Nomor 64 Tahun 1995, Tambahan Lembaran Negara Nomor 3606.

Peraturan Otoritas Jasa Keuangan Nomor 15/ POJK.04/2015 tentang Penerapan Prinsip Syariah di Pasar Modal.

Peraturan Otoritas Jasa Keuangan Nomor 16/ POJK.04/2015 tentang Ahli Syariah Pasar Modal.

Peraturan Otoritas Jasa Keuangan Nomor 17/ POJK.04/2015 tentang Penerbitan dan Persyaratan Efek Syariah Berupa Saham oleh Emiten Syariah atau Perusahaan Publik Syariah. 
Peraturan Otoritas Jasa Keuangan Nomor 18/ POJK.04/2015 tentang Penerbitan dan Persyaratan Sukuk.

Peraturan Otoritas Jasa Keuangan Nomor 19/ POJK.04/2015 tentang Penerbitan dan Persyaratan Reksadana Syariah.

Peraturan Otoritas Jasa Keuangan Nomor 20/ POJK.04/2015 tentang Penerbitan dan Persyaratan Efek Beragun Aset Syariah.

Peraturan Otoritas Jasa Keuangan Nomor 20/ POJK.04/2015 tentang Akad yang Digunakan dalam Penerbitan Efek Syariah di Pasar Modal.

Keputusan Fatwa Majelis Ulama Indonesia Nomor 1 Tahun 2004 tentang Bunga (Interest/Fa'idah).

\section{Books:}

Abidin, Ibnu, Muhammad Amin Bin Umar, 1998, Hasyiah Radd al-Mukhtar ala Durr al-Mukhtar, Mesir: Dar Mustafa al-Baby al-Halaby.

Adam, Nathif J. dan Abdulkader Thomas, 2004, Islamic Bonda, Your Guide to Isuing, Structuring and Investing in Sukuk, London: Euromoney Books.

Ahmad, Khurshid, 1998, Studies in Islamic Economic, United Kingdom and King Abdul Aziz University, Jeddah: The Islamic Foundatioan.

Al-Assal, Ahmad Muhammad, 1999, Sistem, Prinsip, dan Tujuan Ekonomi Islam, Terj. Drs. H. Imam Saefudin, Bandung: Pustaka Setia.

Islahi, Abdul Aziim, 1988, Economic Concept of Ibnu Taimiyyah, Leicester: The Islamic Foudation.

Musa, Muhammad Yusuf, 1952, Al-Amwal wa nazariyyat al-'aqad fi al-Figh al-Iskamiy, Mesir: Dar al-kutub al-Arabiy.
S. Burhanuddin, 2009, Pasar Modal Syariah(Tinjauan Hukum), Yogyakarta: UII Press.

Soekanto, Soerjono, 1986, Pengantar Penelitian Hukum, Jakarta: Universitas Indonesia Press.

Soemitra, Andri, 2010, Bank dan Lembaga Keuangan Syariah, Jakarta: Kencana.

Soemitro, Ronny Hanitijo, 1994, Metodologi Penelitian Hukum dan Jurimetri, Jakarta: Ghalia Indonesia.

Untung, Budi, 2011, Hukum Bisnis Pasar Modal, Yogyakarta: Andi.

Wahid, Nazaruddin Abdul, 2010, Sukuk, Yogyakarta: Ar-Ruzz Media.

\section{Others:}

Zawya, Sukuk Perceptions and Forecast Study 2014, http://www.iefpedia.com/english/wp-content/ uploads/2014/01/tr-sukuk-perceptions-andforecast-20143.pdf acessed on 1 August 2017 , Sukuk Perceptions and Forecast Study 2015, http://www.iefpedia.com/english/wpcontent/uploads/2014/01/tr-sukuk-perceptionsand-forecast-20143.pdf acessed on 1 August 2017

Administrator, 2015, Profil Pasar Modal, http:// www.bapepam.go.id.

Bakar, Mohd Daud, Structuring Islamic PDS; Role of Independent Syari'ah Adviser, Seminar on Islamic Private Debt Securities (IPDS), Malaysia: Suruhanjaya Sekoriti, 24-25 September 2001.

Bapepam-LK, Kajian Pasar Seknnder Efek Syariah di Pasar Modal Indonesia, http://bapepam.go.id/ syariah/publikasi/riset/index.html. 